\title{
Study on Cultural Brand of Harbin Wheat Stalk Artwork*
}

\author{
Xue Jiang \\ School of Art and Design \\ Harbin University of Commerce \\ Harbin, China 150028
}

\author{
Xiaohui Zhang \\ School of Art and Design \\ Harbin University of Commerce \\ Harbin, China 150028
}

\begin{abstract}
Combining the cultural brand development strategy of Harbin wheat Stalkartworks with the internal resources and external environment of its own construction, and comprehensivly analyzing these factors, to explore the feasible path of cultural brand of Harbin wheat stalk artworks. Through the combination of theoretical analysis and practice, with the perspective of interaction principle as the innovation point, the author explores a feasible path for the cultural brand construction of Harbin wheat Stalkartworks to effectively serve the "One Belt and One Road" project construction and Harbin ice-snow cultural tourism construction.
\end{abstract}

Keywords-wheat stalk artwork; "One Belt and One Road"; brand research

\section{INTRODUCTION}

At the moment, China is undergoing an important period of transition in history. Under the background of economic globalization and national modernization, folk art is facing an unprecedented impact, and its living environment changes dramaticly and profoundly. Re-finding the position of folk art in modern life is the need for social development. On December 3, 2014, the Ministry of Culture issued an announcement that Harbin wheat stalk clip art was included in the national intangible cultural heritage list. The approval of the state-level intangible cultural heritage has brought this art object with Northeast folk characteristics into our sight.

\section{RESEARCH BACKGROUND OF HARBIN WHEAT STALKARTWORK}

In 2015, the Harbin cultural industry rose in a great momentum, realizing an industry added value of 27 billion yuan, accounting for $6.4 \%$ of GDP, and becoming a new growth point and pillar industry for the national economy. The formation of a rich and prosperous market for folk art and souvenirs will strongly promote the prosperity and development of tourism in our province, enhance the quality of tourism culture, and form a new landscape of cultural tourism.

Non-material cultural heritage ---- wheat stalk artworks, also known as Stalkpainting, has a history ofmore than two

*Project title: Heilongjiang Province Philosophy and Social Science Research Planning Project "Constructive Study on Protection and Culture Brand of Harbin Wheat Stalk Artwork"

Project number: 17YSE378 thousand years in China and more than one hundred years in Harbin. After decades of improvements in the production process, we have developed more than a series of tapes of paintingswith more than 50 varieties and more than 2,000 kinds of colors, such as landscapes, flowers and birds, figures, animals, flowersand plants, Bogu, and architecture, which has been hailed as "a unique piece of Chinese folk art" and has gone abroad to serve as a UNESCO outstanding handicraft badge and Heilongjiang intangible cultural heritage. Wheat stalk artworks are well-known both at home and abroad. They have won many awards at the World Expo. The products have been awarded the Provincial Arts and Crafts Baihua Award for several consecutive years since 1981. In 1982, Hong Kong Ta Kung Pao specially provided special reports on the development and characteristics of Harbin wheat stalk artworks. As a state-level intangible cultural heritage, key cultural characteristics works of the Ministry of Culture, the Harbin wheat stalk artworks focus on innovation and creativity, so that the traditional industries and industries get a higher industrial value.

Books and literature on this research are scarce, and the relevant articles are mostly on the shallower level, such as $\mathrm{Li}$ Li's "Preliminary Study on the Artistic Characteristics of the Henan wheat stalk artworks", Zhang Min and Cui Xiaojing's "On the development of Puyang wheat stalk painting and the National Arts and Crafts". They mainly study on the production process and aesthetic value of wheat stalk artworkss in the Puyang area of Henan Province and the transformation of the commercialization of handicrafts. Gong Lihui's "Inheritance, development and artistic value of wheat stalk artworks in western Liaoning"mainly studies the social value and artistic value of wheat stalkpainting in western Liaoning. "Making the art of craftsmanship and craftsmanship in traditional Chinese handicrafts-Analysis on the aesthetic value of wheat stalk artworks" mainly analyzes the aesthetic features of wheat wheat stalk artworkss and the existing forms of wheat stalk artworkss from the perspective of arts and crafts. "Harbin wheat stalkpainting with gorgeous and simple demeanor", Ding Ru "Li Youshu: Lighting up the wheat stalkpainting with another burning fire", Wang Mei "Popularizing folk art, passionatingvocational education Interview with Liu Yongming, inheritor of Anfeng wheat stalk artworks", A Sang's article "The wheat stalk artworks into the Guinness Book of World Records - China's folk art and craftsman Shen Sheguo" and other articles are introductions 
and interviews of representativeworks of wheat stalk artworks inheritors in various regions of China. At present, the study of wheat stalk artworks in China mainly focuses on theoretical discussions and introductions by famous artists. It mostly focuses on aesthetic research and inheritance and protection strategies of wheat stalk artworks. There is a lack of research on the brand building of Harbin wheat stalk artworks and fusion developmental research based on other related disciplines, such as communication science and big data information processing technology.

The study of Harbin wheatstalk artworks is a comprehensive study. By integrating the interdisciplinary sociology interaction principle and the protection of Harbin wheat stalk artworks, it has broken through the previous oneway protection research. With the development of related disciplines, it can provide new ideas, new goals, new developments for Harbin wheatstalk artworks protection. Combining multiple channels, we use the "five-W model" of Lasswell in Communication to promote the cultural brand communication of Harbin wheat stalk artworks, make full use of the mass media and new media to increase the spread of cultural brands and the scope of the audience, and promote the formation of society cultural hot spots and extend the cultural brand value chain. This is a new exploration from the perspective of theoretical research, it can provide more ideas for the protection of Harbin intangible cultural heritage and the development of cultural brands in the later period. The deep integration of the "One Belt and One Road" strategy promoted by the state has multiple important role in promoting interethnic cultural exchanges and innovation, enhancing national cohesion, and stimulating economic development through cultural exchange.

\section{ANALYSIS OF THE CULTURAL BRAND CONSTRUCTION PATH OF HARBIN WHEAT STALK ARWORKS}

The Harbin wheat stalk artworks have distinctive national characteristics, strong nationalness and local characteristics, and its representative works can express the unique personality and aesthetic sense of Heilongjiang people. We can appreciate its practicality and appreciation, history and national culture, festival folklore, and cultural blending in the Harbin wheat stalk artworks, which has a distinct artistic style. In addition to the traditional and innovative techniques, Harbin wheat stalk artworkshas developed natural, fresh, concise and honest artistic features in terms of materials, techniques, color matching and technological procedures. Its artistic language and cultural inheritance is an art aesthetic value and art style of self-contained faction that is formed spontaneously in production and labor activities of folk artisans and art lovers.The art language and style are especially typical, and their design and composition concept all are more mature and form a representative regional language symbol.

Heilongjiang is a major ecotourism province in northern China. As China continues to push forward the "One Belt and One Road" initiative, it has deeply integrated the national "One Belt and One Road" strategy and has actively participated in the construction of the China-Mongolia-Russia
Economic Corridor. As China's economic and trade activities with countries in Asia, Africa, and Latin America have become increasingly frequent and business activities continue to deepen, exchanges between countries in Asia, Africa, and Latin America and China's culture have become increasingly active. As the essence of national culture, the Longjiang intangible cultural heritage wheat stalk artworkshas the multiple functions of promoting inter-ethnic cultural exchange and innovation, and enhancing national cohesion.

The protection of Harbin wheat stalk artworksshould not only proceed from its excellent connotation, but also be based on the actual situation of Heilongjiang's cultural development and rely on the strength of the government, the market and the people to cooperate with each other. Only protecting the cultural and ecological environment that gestates handicrafts, can the foundation continue to provide a steady stream of strength. It is necessary to change the notion that only attached importance to the value of art in the past and recognize that its economic value also plays a non-negligible role in the protection of Harbin wheat stalk artworks, but also to guide the establishment of a good economic development model, while implementing protection for the local people, at the same time, creating substantial interest income to promote common development of culture and economy. Under the premise of rational and orderly development of cultural resources, protecting cultural ecology, inheriting and developing national culture to retain China's outstanding traditional arts and crafts culture.

As a representative regional language symbol of Harbin, wheat stalk artworks integrates its systematic development and design and the construction of cultural brands into the construction system of Harbin ice-snow Famous City, which has a driving effect in the protection and inheritance of wheat stalk artworks and ice-snow fanous city. The introduction of Harbin wheat stalk artworks into the development of tourism can enable its cultural connotation value to be realized, so as to obtain more protection funds and development momentum. The protection of wheat stalk artworksfurther promotes the exploration of its cultural value, the further realization of economic value and social value, and thus the level of tourism products and projects have been further improved, eventually forming a benign interaction between its protection and tourism development.

The brand development and construction of Harbin wheat stalk artworks need to be studied from three aspects: the practicability, culture and innovation. Exploring how to reintegrate the spiritual elements and modern design language of Harbin wheat stalk artworks to give new features of the times and practical value, ideological connotation and broad developmentprospects.

Carry forward the culture of black soil and customs culture of Heilongjiang minorities, and take it as a basis for establishing the cultural brand of Harbin wheat stalk artworks, form an advantageous industrial chain and industrial clusters, and promote the development of the Heilongjiang art works industry. 


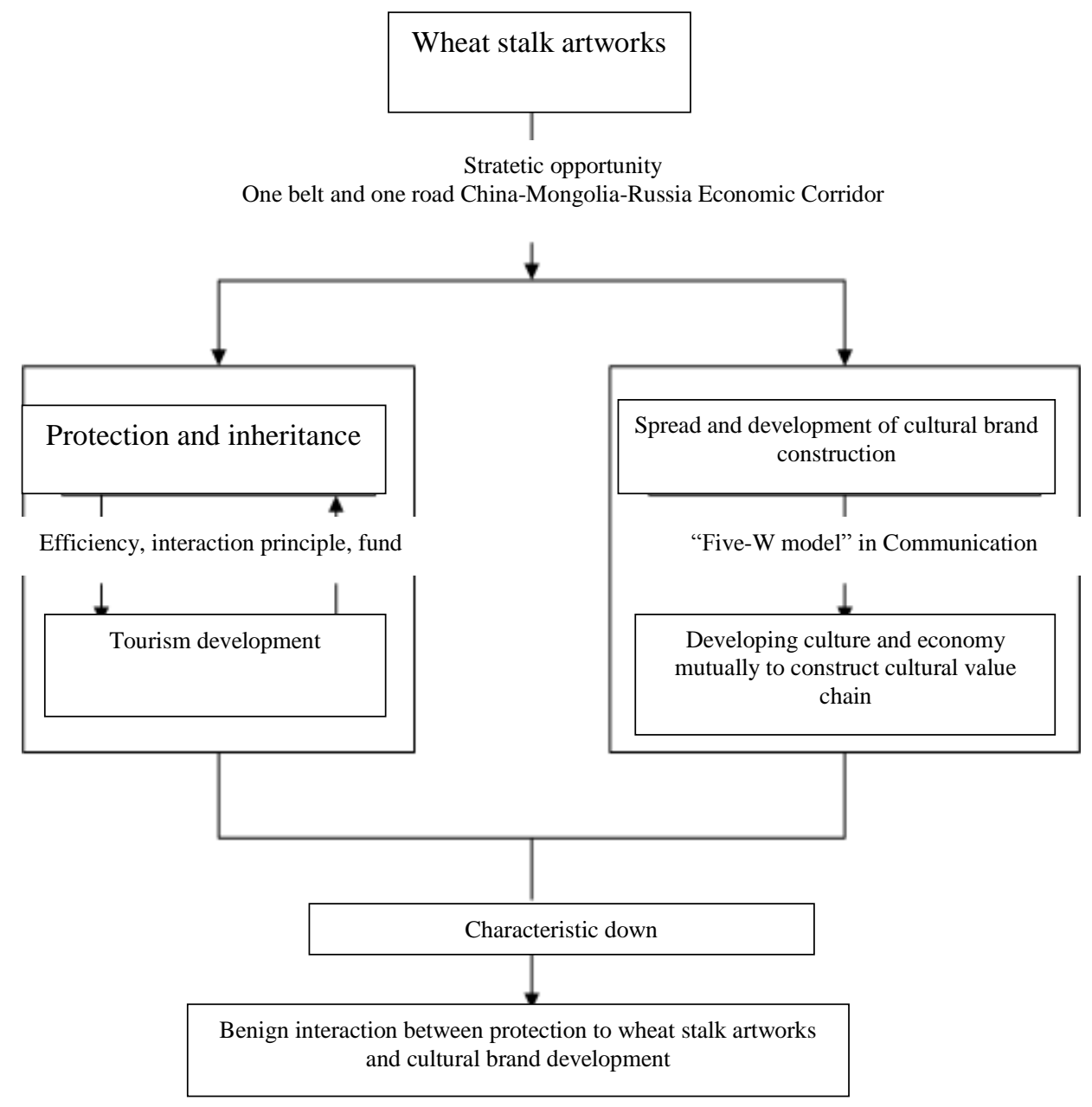

Fig. 1. Wheat stalk artworks.

\section{HARbin WhEAT STALK ARTWORKS AND CUlTURAL BRAND RESEARCH IDEAS}

\section{A. Protection Research}

The protection and inheritance of an art culture is determined by its own cultural connotation value; second, it is determined by people's emphasis on their degree of publicity, promotion and protection. Under the background of economic globalization and diversification, traditional national culture faces the dual task of protection and development, and the Heilongjiang Non-tangible cultural heritagewheat stalk artworksis not exceptional. To tap cultural resources and build cultural brands, the first task is to further collect and summarize the existing information, and record and preserve it with modern technology. To maintain and promote the development of the cultural brand of wheat stalk artworks, and ensure continuity and inheritance in modern society, we should maintain the original essence of its cultural connotation. Nowadays, as traditions continue to shift towards modernality, there is an irresistible change in the connotation and extension of national culture. This requires the study of related disciplines such as anthropology and folklore.

\section{B. Cultural Brand Construction}

Design of Harbin wheat stalk artworks focuses on cultura connotation and brand image feature. It is creative, and expresses its regional characteristics and folk features by traditional local artistic visual symbols to arouse people's emotional resonance and cultural identity, which is the embodiment of the cultural brand concept.

\section{Characteristics of Cultural Brand Image}

Artworks is a bearing object of a specific culture. The expression and embodiment of its culture are materialized. The cultural connotation is expressed through the externalized material form. The aethestics of artworks' externalization is the effective way to spread the recognition of culture. Integrating the cultural brand of Harbin wheat stalk artworks into the construction system of Harbin Ice-snow city, the author finds that the development of famous cities for ice and snow tourism should proceed from the cultural industry and tourism environment, and formulate cultural brand development strategy for Harbin wheat stalk artworks and take it as a tourist handicraft culture. Research on brand 
development strategy has important role in cultural heritage and application.

\section{Propaganda and Development of Cultural Brands}

By building a cultural brand of Harbin wheat stalk artworks, the popularity of Harbin wheat stalk artworks will be increased as the famous tourism crafts in Harbin, and the market share will be increased to establish its own local characteristics and enhance brand value. Its distinctive cultural personality attracts consumers and provides strong support for the development of Harbin Ice-snow tourism city.

\section{SPECIFIC RESEARCH METHODS, RESEARCH PLANS AND} FEASIBILITY ANALYSIS ON HARBIN WHEAT STALK ARTWORKS BRAND BUILDING

\section{A. Practical Investigation and Analysis}

By research and understanding of the development history of Harbin wheat stalk artworks, make overall plans and researches on artistic culture, regional culture and artistic emotional language expression of wheat stalk artworks, and make summary based on the influence of these factors on Harbin wheat stalk artworks.

\section{B. Literature Research Method}

First of all, through reviewing a large number of literature searches and newspapers and magazines, sum up and review the previous research results and clarify the relationship. Refine, arrange and summarize the relevant knowledge points to provide theoretical references and data supporting for further systematic research.

\section{Example Analysis Method}

Through the analysis of the best-selling and artistic wheat stalk artworks on the market, learn from the experience and seek ideas for the cultural brand construction of Harbin wheat stalk artworks.

\section{Data Analysis Method}

Based on the big data of market sales, main regions, the age structure of the main purchase groups, and the best-selling styles of the Harbin wheat stalk artworks, analyze and obtain data to provide the basis for cultural brand building and development of the Harbin wheat stalk artworks.

\section{HARbin WheAT STALK ARTWORKS CUltural BRAND INNOVATION}

Applying big data analysis technology to the study of wheat stalk artworkscultural brand, analyzing the audience category, age structure and best-selling style data provide data technology basis for the development research of Harbin wheat stalk artworks. At the same time, the effective combination of big data technology and cultural and artistic resources platforms has made it possible for cultural communicators to quantify the details of public demand, review behavior, appreciation emotions, and evaluation of cultural resources.
Combine multiple channels and make full use of the mass media and new media to increase the cultural communication. To broaden the cultural brand of the intangible cultural heritage of wheat stalk aerworks in Heilongjiang, the brand should be promoted through multiple channels and multiple ways such as organic integration of books, text, pictures, audio and video. Introduce Laswell's "five-W mode" in communication science. Based on the "5W model", the cultural brand of Harbin wheat stalk artworks will be further promoted, and the mass media and new media will be fully utilized to increase the spread of cultural brands and the scope of the audience. This will promote the formation of social and cultural hotspots and extend the value chain of cultural brands.

Break through the traditional one-way design concept and introduce interactive principles. According to the principle of interaction, under the force of the leading role, the protection factor and the tourism development factor will have an interactive process undergone imaginative preview, strengthened guidance and role understanding. During this process, both the protection factor and the tourism development factor have changed. And their influence objects-that is, the intangible cultural heritages will be promoted to finish transition, and then drive the cultural and economic structure of this composition to move forward, and more effectively provide new ideas for the development of Harbin wheat stalk artworks.

\section{CONCLUSION}

In conjunction with July 2016, the Ministry of Housing and Construction and the National Development and Reform Commission decided to develop characteristic townships nationwide. It is planned to introduce the intangible cultural heritage such as Harbin wheat stalk artworks in the form of an experience hall into the pilot construction of a state-level featured town - Maple Leaf Town, Songbei District, Harbin. As a special attraction in the cultural tourism of the featured towns of leisure shopping, cultural tourism, ice-snow entertainment, featured agriculture, and ecological pension, the new cultural industry is being promoted, created and upgraded with new ideas, new mechanisms, and new carriers.

\section{REFERENCES}

[1] Liu Chen "Analyzing the Aesthetic Value of Chinese Traditional Handicrafts - Wheat stalk artworks” 刘琛《材美工巧中国传统手工艺 一麦秸画美学价值探析》

[2] Zhao Shengnan "A Study on Cultural Construction of Folk Crafts in Heilongjiang Province". 赵胜男《黑龙江民间工艺品文化品牌建设研 究》

[3] Li Feifei Development and Exploration on Heilongjiang Folk Art Industrialization. 李菲菲《黑龙江民间艺术产业化发展与探索》 